DOI: http://doi.org/10.4038/slemaj.v18i2.16

\title{
Economic Evaluation of Pumped Storage Power Plant Complexes and Comparison with other Candidate Pumped Storage Power Plants Proposed for Sri Lanka
}

\author{
MTAP Wickramarathna \\ BSc Eng. (Hons) (Moratuwa), MSc (Moratuwa), MSc (Sweden), C.Eng., MIE (SL), Member SLEMA \\ Electrical Engineer, Ceylon Electricity Board, P O Box 540, Colombo, Sri Lanka
}

Key word: pumped storage power plant complex, construction cost, B/C, EIRR

\begin{abstract}
The daily electricity demand in Sri Lanka varies significantly with the time. The maximum demand occurs between $0630 \mathrm{pm}$ to $0930 \mathrm{pm}$ and the lowest demand occurs between 0030am to 0430am. The maximum demand is more than twice the lowest demand. According to the Ceylon Electricity Board (CEB) Long Term Generation Plan 2013 2032, sixteen coal power plants amounting to $4,700 \mathrm{MW}$ capacity will be added to the Sri Lanka power system in future. For economic operation of coal power plants in a power system which has significantly varying load throughout the day, energy storage mechanisms such as Pumped Storage Power Plant (PSPP) are required.
\end{abstract}

The studies reveal that Sri Lanka has several attractive natural sites for Pumped Storage Power Plants, among them two sites can be developed as Pumped Storage Power Plant Complexes (PSPPC). This paper present the economic evaluation of possible sites and the findings shows that developing 1,000MW Maha Pumped Storage Power Plant Complex would be the most economical candidate site when considering the capacity requirement with the time.

\section{Calculation Method}

The calculations were done by the measured values based on layouts done on 1:10,000 scale topographical maps and formulae based on the quantities of existing facilities. These formulae used were developed in Japan for the purpose of the hydropower potential studies. They are prepared for each facility considering factors such as intake weir, intake, and headrace etc. The quantities of civil works are calculated for main work items such as excavation, concrete, embankment, reinforcement bars, gates, screens, and steel conduits.

Following symbols and units are used in the calculation. $\mathrm{V}_{\mathrm{e}}\left(\right.$ :Excavation volume in $\left.\mathrm{m}^{3}\right)$, $\mathrm{V}_{\mathrm{c}}\left(\right.$ :Concrete volume in $\left.\mathrm{m}^{3}\right), \mathrm{V}_{\mathrm{f}}($ :Dam embankment volume for fill dam inm $\left.{ }^{3}\right), \mathrm{W}_{\mathrm{r}}($ :Weight of reinforcement bars in ton), $\mathrm{W}_{\mathrm{g}}($ :Weight of gate in ton), $W_{\mathrm{p}}(:$ Weight of steel conduit in ton), $\mathrm{W}_{\mathrm{s}}($ :Weight of screen in ton).

Quantities of work items other than main work items are not calculated. However, their costs are calculated as "others" in a lump-sum at a certain ratio against the total cost of main work items. Quantities of works of headrace tunnels and penstock are calculated based on their inner diameters.

\section{Conditions for Construction Cost Estimate}

Construction costs calculations are described in Table 5 for Maha PSPPC. In the preparatory works, costs of access roads, camp \& facilities are calculated based on quantity of civil works, and the percentage cost are calculated making reference to actual costs of similar projects. For access road as $5 \%$ for pumped storage type of the total cost of civil works is estimated. While camp \& facility cost as 3\% and Environment mitigation cost as $3 \%$. The cost of civil works and hydraulic equipment are calculated by multiplying the quantity of main items of works by unit cost which is described in Table 3 and Table 4 for Maha PSPPC. The work quantity is obtained from tables, diagrams and numerical formula. In this evaluation, the main work items of structures of civil works are excavation, concrete, embankment, and reinforcement bars and those of hydraulic equipment are gate, screen, and steel pipe. The costs of rest of the items of work, other than the main items, are calculated as "Others" in a lumpsum at a certain ratio against the total cost of the main work items. Unit costs are obtained by making reference to the latest data of similar works in Sri Lanka's Upper Kotmale Hydropower Project.

The construction costs of turbines, generators, control devices and main transformers, etc. are appropriated in a lump-sum in "Electromechanical equipment". There is a relationship that it is almost a straight line on logarithmic paper between electro-mechanical equipment cost 
according to each turbine type and $\mathrm{P} / \sqrt{\mathrm{He}}(\mathrm{P}$ : maximum output in $\mathrm{kW}$ ), He (:effective head in meters), as shown in the example in Figure 1 and escalated as required.

In this paper, the construction cost of transmission lines is not considered. The following are included in the costs of "administration", "engineering service", "contingencies", which are calculated by multiplying the direct construction cost by an appropriate ratio. The administration cost includes personnel expense and expenses to maintain the construction office. The engineering service cost includes expenses related to technical services such as design work and construction supervision conducted by consultants. In this evaluation, $15 \%$ of the direct construction cost is appropriated as the cost of administration and engineering service. The contingency includes physical contingency which is the increase of quantities of work, and $10 \%$ of the direct construction cost is appropriated for the contingencies. Interest during construction is calculated based on the following conditions.

\section{Figure 1 - Example of Electro-Mechanical Equipment Cost}

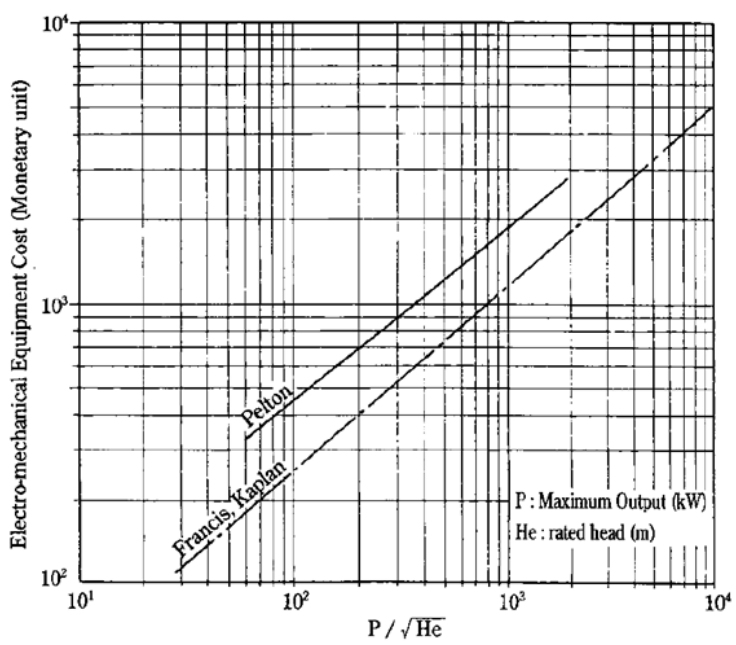

Example of Electro-mechanical Equipment Cost

Weighted average interest rate (i) is calculated taking into account the ratio of local currency and foreign currency. For example, if the local and foreign currency portions are $25 \%$ and $75 \%$ respectively the calculation is as follow.

$\mathrm{i}=\mathrm{i}_{1} \times 0.25+\mathrm{i}_{2} \times 0.75=6.05 \%$

$\mathrm{i}_{1}$ : Interest rate for local currency $=20 \%$

$\mathrm{i}_{2}$ : Interest rate for foreign currency $=1.4 \%$

Interest during construction

$=($ cost of preparatory works + cost of environmental mitigation + cost of civil works + cost of hydraulic equipment + cost of electro mechanical equipment + cost of administration and engineering service + contingency) $\times 0.4 \times \mathrm{i} \times$ $\mathrm{T}$, where,

$\mathrm{T}:$ Construction period (years) $=5$ years

The value of 0.4 is a cash flow coefficient which is an empirical value for existing projects.

\section{Quantities of work for Maha Pumped Storage Power Plant Complex}

\section{Uduwella Pumped Storage Power Plant}

\section{Uduwella PSPP -Upper Dam}

(1) Structural Design

Rock fill type dam is adopted because of the following reasons.

Environment friendly type to harmonize with the estate (integration with nature, gentle inclination with nature rock), Catchment area is narrow, Possible to utilize the excavated material, Difficult to transport concrete

Dam specifications are determined as below.

Crest Elevation:719 m; Crest Length:340 m; Dam Height $\left(\mathrm{H}_{\mathrm{d}}\right): 32 \mathrm{~m}$

Data such as Creager's curve should be used to calculate the design flood discharge if available. In case such data are not available, it is estimated by using annual rainfall, and the following simplified formula should be used as reference.

$$
\begin{aligned}
& Q_{f}=q \times A \\
& q=a \times A^{\left(A^{-0.05}-1\right)}
\end{aligned}
$$

$\mathrm{Q}_{\mathrm{f}}$ : Design flood discharge $\left(\mathrm{m}^{3} / \mathrm{s}\right) ; \mathrm{q}$ : Specific discharge $\left(\mathrm{m}^{3} / \mathrm{s} / \mathrm{km}^{2}\right) ; \mathrm{a}:$ Region coefficient $=100$; A : Catchment area $\left(\mathrm{km}^{2}\right): 4.8754 \mathrm{~km}^{2}$

$$
Q_{f}=432 \mathrm{~m}^{3} / \mathrm{s}
$$

(2) Quantity of work

i) Rock fill dam

Excavation and filling volume of dam are obtained by the following equations.

$V_{e}=10.0 \times H_{d} \times L$

$V_{c}=1 / 6 \times(m+n) \times H_{d}^{2} \times(L+2 \times B)+W / 2 \times H_{d}$

$$
\times(L+B)
$$

$\mathrm{H}_{\mathrm{d}}$ : Dam height $(\mathrm{m}): 32 \mathrm{~m}$; L: Dam crest length $(\mathrm{m})$ : $340 \mathrm{~m}$; B: River bed width (m): $60 \mathrm{~m}$; W: Crest width : $10 \mathrm{~m} ; \mathrm{m}$ : Upstream slope of dam $(\mathrm{m}=2.0$ in this Manual); $\mathrm{n}$ : Downstream slope of dam ( $\mathrm{n}=1.8$ in this Manual) 
$\mathrm{V}_{\mathrm{e}}=108,800 \mathrm{~m}^{3} ; \mathrm{V}_{\mathrm{c}}=362,325 \mathrm{~m}^{3}$

Cost of other items of works such as grouting not included in the main items described above is estimated at $20 \%$ of the cost of the main items.

ii) Spillway

In the case of a fill type dam, the quantity of work of the spillway is calculated by the design flood discharge.

The excavation volume, concrete volume, weight of reinforcement bars, and weight of gates are calculated according to the following equations.

$V_{e}=84 \times \sqrt{ } Q_{f} \times H_{d}$

$V_{c}=13 \times \sqrt{ } Q_{f} \times H_{d}$

$W_{r}=0.02 \times V_{c}$

$W_{g}=0.22 \times Q_{f}$

$\mathrm{Q}_{\mathrm{f}}$ : Design flood discharge $(\mathrm{m} 3 / \mathrm{s}): 432 \mathrm{~m}^{3} / \mathrm{s}$

$\mathrm{H}_{\mathrm{d}}$ : Dam height $(\mathrm{m}): 32 \mathrm{~m}$

$\mathrm{V}_{\mathrm{e}}=55,878 \mathrm{~m}^{3} ; \mathrm{V}_{\mathrm{c}}=8,648 \mathrm{~m}^{3} ; \mathrm{W}_{\mathrm{r}}=173$ ton;

$\mathrm{W}_{\mathrm{g}}=95$ ton

Cost of other items of works which is not included in the main items described above is estimated at $20 \%$ of the cost of the main items.

\section{Allugolla PSPP - Upper Dam}

(1) Structural Design

Concrete gravity type dam is adopted because of the following reasons.

Possible to obtain the sound rock for the dam foundation, River span is narrow, Easy to overflow during the flood period, Easy to transport concrete.

Dam specifications are determined as below. Crest Elevation:819 m; Crest Length:260 m; Dam Height $\left(\mathrm{H}_{\mathrm{d}}\right): 41 \mathrm{~m}$

$$
Q_{f}=259.467 \mathrm{~m}^{3} / \mathrm{s}
$$

(2) Quantity of work

Excavation volume and volume of dam is obtained by the following equations.

$\mathrm{V}_{\mathrm{e}}=10.0 \times H_{d} \times \mathrm{L}$

In the case $: H_{d}{ }^{2} \times L>100 \times 10^{3}$

$V_{C}=0.34 \times\left(H_{d}{ }^{2} \times L\right) \quad(B / L=0.5)$

$V_{C}=0.30 \times\left(H_{d}{ }^{2} \times L\right) \quad(B / L=0.4)$

$V_{C}=0.27 \times\left(H_{d}^{2} \times L\right) \quad(B / L=0.3)$

$V_{C}=0.21 \times\left(H_{d}^{2} \times L\right) \quad(B / L=0.2)$

$V_{C}=0.16 \times\left(H_{d}{ }^{2} \times L\right) \quad(B / L=0.1)$

$$
\mathrm{W}_{\mathrm{g}}=0.13 \times \mathrm{Q}_{\mathrm{f}}
$$

B : River bed width $(\mathrm{m}): 35 \mathrm{~m}$; L : Crest length (m) : $260 \mathrm{~m} ; \mathrm{Q}_{\mathrm{f}}$ : Design flood discharge : 259.5 $\mathrm{m}^{3} / \mathrm{s} ; \mathrm{H}_{\mathrm{d}}$ : Dam height $(\mathrm{m}): 41 \mathrm{~m}$

$\mathrm{V}_{\mathrm{e}} \approx 106,600.00 \mathrm{~m}^{3}$

$\mathrm{V}_{\mathrm{c}} \approx 69,929.60 \mathrm{~m}^{3}$

$\mathrm{W}_{\mathrm{g}} \approx 33.7$ ton

Cost of other items of civil works such as grouting and coffering not included in the main items above, is estimated at $20 \%$ of the main items.

\section{Lower Dam - Arama Lower Dam}

(1) Structural Design

Concrete gravity type dam is adopted.

Dam specifications are determined as below.

Crest Elevation:305 m; Crest Length: 350 m; Dam Height $\left(\mathrm{H}_{\mathrm{d}}\right): 57 \mathrm{~m}$

$$
Q_{f}=1206 \mathrm{~m}^{3} / \mathrm{s}
$$

B : River bed width $(\mathrm{m}): 45 \mathrm{~m}$; L : Crest length (m) : $350 \mathrm{~m} ; \mathrm{Q}_{\mathrm{f}}$ : Design flood discharge : 1206 $\mathrm{m}^{3} / \mathrm{s} ; \mathrm{H}_{\mathrm{d}}$ : Dam height $(\mathrm{m})$

$\mathrm{V} \approx 199,500 \mathrm{~m}^{3}$

$\mathrm{V}_{\mathrm{c}} \approx 181,944 \mathrm{~m}^{3}$

$\mathrm{W}_{\mathrm{g}} \approx 156.8$ ton

Cost of other items of civil works such as grouting and coffering not included in the main items above, is estimated at $20 \%$ of the main items.

\section{Uduwella PSPP - Intake}

(1) Structural Design

A pressure type is adopted. The inner diameter of waterway is obtained from Figure 2 . by using the maximum plant discharge.

Inner Diameter: $6.9 \mathrm{~m}$

Maximum plant discharge: $152 \mathrm{~m}^{3} / \mathrm{s}$

Figure 2 - Inner Diameter of Waterway

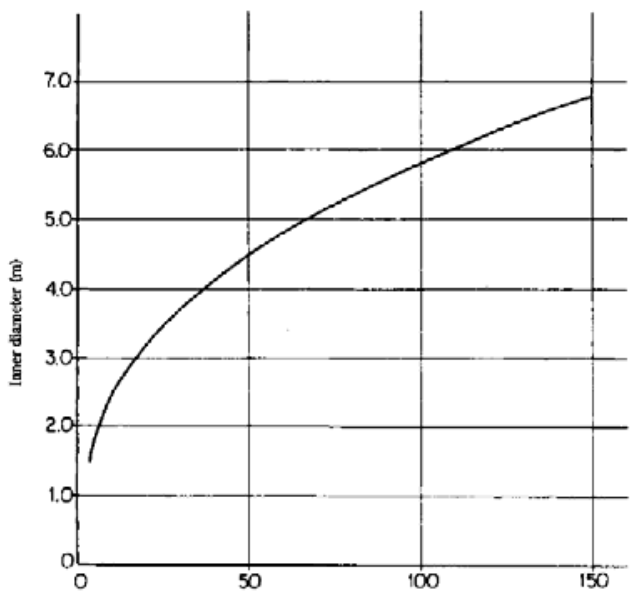


(2) Quantity of work

The excavation volume, concrete volume, weights of reinforcement bars, gate and screen are calculated by the following equations.

$$
\begin{aligned}
& V_{e}=130 \times\left[\left\{\left(h_{a}+D\right) \times Q\right\}^{1 / 2} \times n^{1 / 3}\right]^{1.27} \\
& V_{c}=56.5 \times\left[\left(\left(h_{a}+D\right) \times Q\right\}^{1 / 2} \times n^{1 / 3}\right]^{1.23} \\
& W_{r}=0.04 \times V_{c} \\
& W_{g}=0.9 \times\left\{\left(h_{a} \times D\right)^{1 / 9}\right\} \times Q \\
& W_{s}=0.5 \times\left\{\left(h_{a} \times D\right)^{1 / 9}\right\} \times Q
\end{aligned}
$$

$\mathrm{h}_{\mathrm{a}}$ : Available drawdown (m) : $19.55 \mathrm{~m}$;

$\mathrm{Q}$ : Maximum plant discharge $\left(\mathrm{m}^{3} / \mathrm{s}\right): 152 \mathrm{~m}^{3} / \mathrm{s}$

$\mathrm{D}$ : Inner diameter of waterway : $6.9 \mathrm{~m}$

$\mathrm{n}$ : Number of waterway channels : 1

$\mathrm{V}_{\mathrm{e}}=25,273 \mathrm{~m}^{3} ; \mathrm{V}_{\mathrm{c}}=9,304 \mathrm{~m}^{3} ; \mathrm{W}_{\mathrm{r}}=372$ ton;

$\mathrm{W}_{\mathrm{g}}=236$ ton; $\mathrm{W}_{\mathrm{s}}=131$ ton

Cost of other items of works such as coffering and trash rack, rake, etc. not included in the main items above are estimated at $25 \%$ of the main items.

\section{Uduwella PSPP - Headrace}

(1) Structural Design

A circular fully lined pressure tunnel is adopted. Diameter of tunnel is calculated assuming that a flow velocity in the tunnel is $6.0 \mathrm{~m} / \mathrm{s}$.

Diameter $=\left(4 \times \frac{Q_{\max }}{6 \pi}\right)^{0.5}=5.7 \mathrm{~m}$

(2) Quantity of work

The excavation volume of the pressure tunnel, concrete volume and weight of reinforcement bars are calculated by the following equations.

$$
\begin{aligned}
& \mathrm{V}_{\mathrm{e}}=3.2 \times\left(\mathrm{R}+\mathrm{t}_{0}\right)^{2} \times \mathrm{L} \times \mathrm{n} \\
& V_{c}=\left\{3.2 \times\left(R+t_{0}\right)^{2}-\pi R^{2}\right\} \times L \times n \\
& W_{r}=0.04 \times \mathrm{V}_{\mathrm{c}}
\end{aligned}
$$

$\mathrm{R}$ : Tunnel radius $(\mathrm{m})=2.85 \mathrm{~m} ; \mathrm{t}_{0}$ : Lining concrete thickness $(\mathrm{m})=55 \mathrm{~cm}$; L: Total length of waterway channels $(\mathrm{m})=1850 \mathrm{~m} ; \mathrm{N}$ : Number of waterway channels $=1$

$$
\begin{aligned}
& \mathrm{V}_{\mathrm{e}}=68,435 \\
& \mathrm{~V}_{\mathrm{c}}=21,250 \\
& W_{r}=850
\end{aligned}
$$

Cost of other items of works such as grouting, adit, ect. Not included in the main items stated above is estimated at $15 \%$ of the cost of the main items.

\section{Uduwella PSPP-Headrace Surge Tank}

(1) Structural Design

Surge tank shall be provided to protect the headrace tunnel against the pressure of water hammer.

(2) Quantity of work

The excavation volume, concrete volume, and weight of reinforcement bars are calculated in accordance with the following equations.

$$
\begin{aligned}
& V_{e}=38 \times q \times\left(h_{a}+L\right)^{1 / 4} \times n \\
& V_{c}=11 \times q \times\left(h_{a}+L\right)^{1 / 4} \times n \\
& W_{r}=0.05 \times V_{c}
\end{aligned}
$$

$\mathrm{q}$ : Design discharge $\left(\mathrm{m}^{3} / \mathrm{s}\right)=152 \mathrm{~m}^{3} / \mathrm{s} ; \mathrm{L}$ : Total length of waterway $(\mathrm{m})=1850 \mathrm{~m}$; a : Available drawdown of regulating pond or reservoir $(\mathrm{m})=$ $19.55 \mathrm{~m} ; \mathrm{n}$ : Number of waterway channels $=1$

$\mathrm{V}_{\mathrm{e}}=37,980 \mathrm{~m}^{3}$

$\mathrm{V}_{\mathrm{c}}=10,994 \mathrm{~m}^{3}$

$\mathrm{W}_{\mathrm{r}}=550$ ton

Cost of other works such as steel lining not included in the main items above is estimated at $20 \%$ of the main items.

\section{Uduwella PSPP - Penstock}

(1) Structural Design

A circular fully steel lined pressure tunnel is adopted. The inner diameter of penstock is calculated assuming that a flow velocity in the penstock is $10 \mathrm{~m} / \mathrm{sec}$.

Diameter : $\left(4 \times \mathrm{Q}_{\max } / 10 \Pi\right)^{0.5}=4.4 \mathrm{~m}$

(2) Quantity of work

For embedded type of penstock, excavation volume and concrete volume are obtained by the following equation, assuming constant thickness of backfill concrete of $60 \mathrm{~cm}$.

$V_{e}=\frac{\pi}{4}\left(D_{m}+2 t\right)^{2} \times L$

$V_{c}=\frac{\pi}{4}\left\{\left(D_{m}+2 t\right)^{2}-D_{m}^{2}\right\} \times L$

$D_{m}$ : Average inner diameter of steel pipe $(m)=4.4$ $\mathrm{m} ; \mathrm{t}$ : Thickness of backfill concrete $(\mathrm{m})=0.6 \mathrm{~m}$; L : Total length of penstock $(\mathrm{m}): 2400 \mathrm{~m}$

$\mathrm{V}_{\mathrm{e}}=59,082 \mathrm{~m}^{3}$

$\mathrm{V}_{\mathrm{c}}=22,608 \mathrm{~m}^{3}$

Cost of other items of works such as grouting, audit, etc. not included in the main items stated above is estimated at $15 \%$ of the cost of the main items. 
The weight of the steel conduit is obtained by the following equations for embedded type in tunnel.

$W_{p}=7.85 \times \pi \times D_{m} \times t_{m} \times 1.1 \times L$

$t_{m}=0.0270 H \times D_{m}+2$

$\mathrm{W}_{\mathrm{p}}$ : Weight of steel conduit (ton)

$t_{\mathrm{m}}$ : Average thickness of steel conduit (mm)

$\mathrm{H}$ : Design head (m) (high water level - tailwater level) $=387.6 \mathrm{~m}$

$\mathrm{W}_{\mathrm{p}}=13,743$ ton

$\mathrm{t}_{\mathrm{m}}=48 \mathrm{~mm}$

\section{Uduwella PSPP -Underground Powerhouse}

\section{(1) Structural Design}

Underground type is adopted for Powerhouse.

(2) Quantity of work

The excavation volume, concrete volume, and weight of reinforcement bars are obtained by the following equations.

$\mathrm{V}_{\mathrm{e}}=27 \times \mathrm{A}+1.3 \times \mathrm{A} \times \mathrm{d}$

$\mathrm{V}_{\mathrm{c}}=15 \times \mathrm{A}$

$\mathrm{W}_{\mathrm{r}}=0.6 \times \mathrm{A}$

Provided that,

$\mathrm{A}=1,798 \mathrm{~m}^{2}$

$\mathrm{Q}$ : Maximum plant discharge $\left(\mathrm{m}^{3} / \mathrm{s}\right)=152 \mathrm{~m}^{3} / \mathrm{s}$;

He : Effective head $(\mathrm{m})=387.6 \mathrm{~m}$;

A : Area of powerhouse $(\mathrm{m} 2)=1,798 \mathrm{~m}^{2}$;

$\mathrm{d}$ : Height of powerhouse $(\mathrm{m})=40 \mathrm{~m}$

$\mathrm{V}_{\mathrm{e}}=142,027 \mathrm{~m}^{3}$

$\mathrm{V}_{\mathrm{c}}=26,967 \mathrm{~m}^{3}$

$\mathrm{W}_{\mathrm{r}}=1,079$ ton

The cost of powerhouse building and transformer chamber is included in $50 \%$ of "Others".

\section{Uduwella PSPP -Tailrace Tunnel}

(1) Structural Design

A circular fully lined pressure tunnel is adopted. Diameter of tunnel is calculated assuming that a flow velocity in the tunnel is $6.0 \mathrm{~m} / \mathrm{sec}$. Diameter: $\left(4 \times \mathrm{Q}_{\max } / 6.0 \Pi\right)^{0.5}=(4 \times 152 / 6.0 \Pi)^{0.5}=5.7 \mathrm{~m}$

(2) Quantity of work

The excavation volume of the pressure tunnel, concrete volume, and weight of reinforcement bars are calculated by the following equations.

$V_{e}=3.2 \times\left(R+t_{0}\right)^{2} \times L \times n$

$V_{c}=\left\{3.2 \times\left(R+t_{0}\right)^{2}-\pi R^{2}\right\} \times L \times n$

$W_{r}=0.04 \times V_{c}$

$\mathrm{R}$ : Tunnel radius $(\mathrm{m})=2.85 \mathrm{~m} ; \mathrm{t} 0$ : Lining concrete thickness $(\mathrm{m})=55 \mathrm{~cm}$; L : Total length of waterway channels $(\mathrm{m})=200 \mathrm{~m}$; $\mathrm{n}$ : Number of waterway channels $=1$

$\mathrm{V}_{\mathrm{e}} \fallingdotseq 7,398 \mathrm{~m}^{3}$

$\mathrm{V}_{\mathrm{c}} \fallingdotseq 2,297 \mathrm{~m}^{3}$
$\mathrm{W}_{\mathrm{r}} \fallingdotseq 92$ ton

Cost of other items of works such as grouting, adit, etc. not included in the main items stated above is estimated at $15 \%$ of the cost of the main items.

Figure 3 - Relationship between Inner Diameter of Tunnel and Lining Concrete Thickness

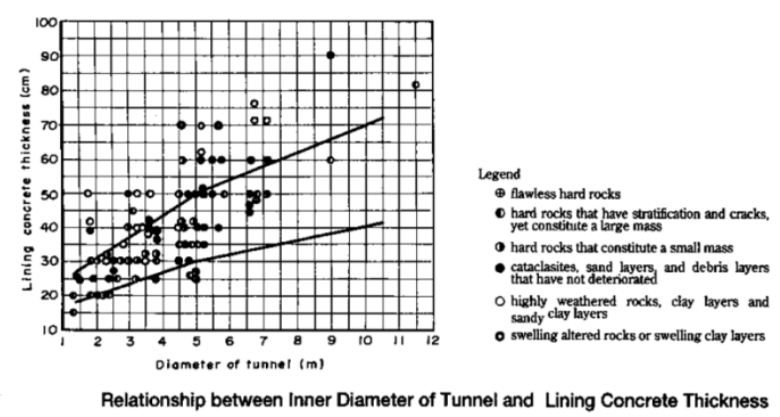

(2) Quantity of work

The excavation volume, concrete volume, and weight of reinforcement bars are calculated in accordance with the following equations.

$V_{e}=38 \times q \times\left(h_{a}+L\right)^{1 / 4} \times n$

$V_{c}=11 \times q \times\left(h_{a}+L\right)^{1 / 4} \times n$

$W_{r}=0.05 \times V_{c}$

$\mathrm{q}$ : Design discharge $\left(\mathrm{m}^{3} / \mathrm{s}\right)=152 \mathrm{~m}^{3} / \mathrm{s} ; \mathrm{L}:$ Total length of waterway $(\mathrm{m})=200 \mathrm{~m}$; $\mathrm{h}_{\mathrm{a}}$ : Available drawdown of regulating pond or reservoir $(\mathrm{m})=$ $33 \mathrm{~m} ; \mathrm{n}$ : Number of waterway channels $=1$

$\mathrm{V}_{\mathrm{e}}=22,566 \mathrm{~m}^{3}$

$\mathrm{V}_{\mathrm{c}}=6,532 \mathrm{~m}^{3}$

$\mathrm{W}_{\mathrm{r}}=327$ ton

Cost of other works such as steel lining not included in the main items above is estimated at $20 \%$ of the main items.

\section{Uduwella PSPP -Tailrace Outlet}

(1) Structural Design

A pressure type is adopted same as the intake.

(2) Quantity of work

During pumping operation the tailrace outlet becomes an intake, therefore, calculation method of quantity of work for intake is adopted.

$\mathrm{Ve}=130 \times\left(((33+5.7) \times 152)^{1 / 2} \times 1^{1 / 3}\right)^{1.27}=32,182 \mathrm{~m} 3$

$\mathrm{Vc}_{\mathrm{c}}=56.5 \times\left(((33+5.7) \times 152)^{1 / 2 \times 1} 1^{1 / 3}\right)^{1.23}=11,758 \mathrm{~m} 3$

$\mathrm{Wr}=0.04 \times 11,758=470$ ton

$\mathrm{Wg}=0.9 \times(33 \times 5.7)^{1 / 9} \times 152=245$ ton

$\mathrm{Ws}=0.5 \times(33 \times 5.7)^{1 / 9} \times 152=136$ ton

Cost of other items of works such as coffering and trash rack, rake, etc. not included in the main items obtained above is estimated at $25 \%$ of the cost of the main items. 


\section{Uduwella PSPP - Access Tunnel to Powerhouse}

(1) Quantity of work

Excavation volume, concrete volume, and weight of reinforcement bars of the access tunnel are obtained by the following equations. The maximum gradient of the access tunnel is $1: 10$.

$\mathrm{V}_{\mathrm{e}}=45 \times \mathrm{L}\left(\mathrm{m}^{3}\right)$

$\mathrm{V}_{\mathrm{c}}=10 \times \mathrm{L}\left(\mathrm{m}^{3}\right)$

$\mathrm{W}_{\mathrm{r}}=0.03 \times \mathrm{V}_{\mathrm{c}}($ ton $)$

$\mathrm{T}$ : thickness of overburden at Powerhouse $=70 \mathrm{~m}$;

$\mathrm{L}$ : Length of access tunnel $(\mathrm{m})=30 \mathrm{~m}$

$\mathrm{V}_{\mathrm{e}}=1,350 \mathrm{~m}^{3}$

$\mathrm{V}_{\mathrm{c}}=300 \mathrm{~m}^{3}$

$\mathrm{W}_{\mathrm{r}}=9$ ton

Cost of other items of works such as grouting, adit, etc. not included in the main items stated

above is estimated at $15 \%$ of the cost of the main items.

\section{Uduwella PSPP -Miscellaneous Works}

Cost of miscellaneous works such as the disposal area and landscaping work is estimated at $10 \%$ of the total civil work cost.

\section{Alugolla PSPP - Intake}

Inner Diameter : $6.4 \mathrm{~m}$

(1) Quantity of work

$\mathrm{V}_{\mathrm{e}}=26,310 \mathrm{~m}^{3}$

$\mathrm{V}_{\mathrm{c}}=9,674 \mathrm{~m}^{3}$

$\mathrm{W}_{\mathrm{r}}=387$ ton

$\mathrm{W}_{\mathrm{g}}=194$ ton

$\mathrm{W}_{\mathrm{s}}=108$ ton

Cost of other items of works such as coffering and trash rack, rake, etc. not included in the main items above are estimated at $25 \%$ of the main items.

\section{Alugolla PSPP - Headrace}

(1) Structural Design

Diameter $=5.0 \mathrm{~m}$

(2) Quantity of work

$$
\mathrm{V}_{\mathrm{e}}=67,680
$$

$\mathrm{V}_{\mathrm{c}}=21,561$

$W_{r}=862$

Cost of other items of works such as grouting, adit, ect. Not included in the main items stated above is estimated at $15 \%$ of the cost of the main items.

\section{Alugolla PSPP - Headrace Surge Tank}

(1) Structural Design

$$
\mathrm{V}_{\mathrm{e}}=32,112 \mathrm{~m}^{3}
$$

$$
\begin{aligned}
& V_{c}=9,295 \mathrm{~m}^{3} \\
& W_{r}=465 \text { ton }
\end{aligned}
$$

Cost of other works such as steel lining not included in the main items above is estimated at $20 \%$ of the main items.

\section{Alugolla PSPP - Penstock}

(1) Structural Design

Diameter : $=3.9 \mathrm{~m}$

(2) Quantity of work

$\mathrm{V}_{\mathrm{e}}=29,951 \mathrm{~m}^{3}$

$\mathrm{V}_{\mathrm{c}}=11,191 \mathrm{~m}^{3}$

$\mathrm{W}_{\mathrm{p}}=7,398$ ton

$\mathrm{t}_{\mathrm{m}}=53 \mathrm{~mm}$

\section{Alugolla PSPP- Underground Powerhouse}

(1) Structural Design

Underground type is adopted for Powerhouse.

(2) Quantity of work

$\mathrm{Q}$ : Maximum plant discharge $(\mathrm{m} 3 / \mathrm{s})=121 \mathrm{~m}^{3} / \mathrm{s}$

$\mathrm{V}_{\mathrm{e}}=136,570 \mathrm{~m}^{3}$

$\mathrm{V}_{\mathrm{c}}=25,931 \mathrm{~m}^{3}$

$\mathrm{W}_{\mathrm{r}}=1,037$ ton

The cost of powerhouse building and transformer chamber is included in $50 \%$ of "Others".

\author{
Alugolla PSPP - Tailrace Tunnel \\ (1) Structural Design \\ Diameter: $\left(4 \times Q_{\max } / 6.0 \Pi\right)^{0.5}=5.1 \mathrm{~m}$ \\ (2) Quantity of work \\ $\mathrm{V}_{\mathrm{e}} \fallingdotseq 12,800 \mathrm{~m}^{3}$ \\ $\mathrm{V}_{\mathrm{c}} \fallingdotseq 4,020 \mathrm{~m}^{3}$ \\ $\mathrm{W}_{\mathrm{r}} \fallingdotseq 161$ ton
}

Cost of other items of works such as grouting, adit, etc. not included in the main items stated above is estimated at $15 \%$ of the cost of the main items.

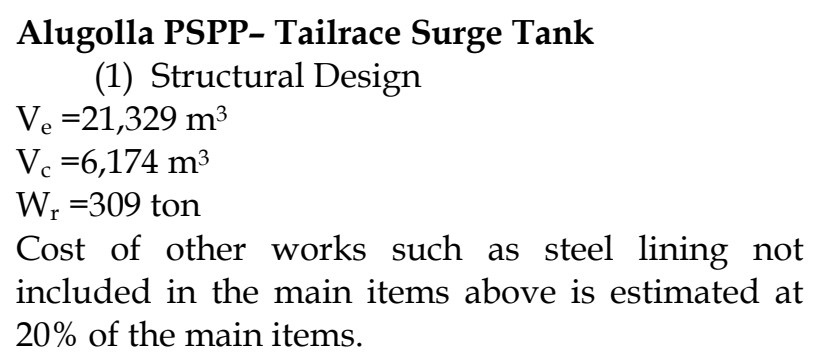

\section{Alugolla PSPP - Tailrace Outlet}

(1) Structural Design

A pressure type is adopted same as the intake.

(2) Quantity of work

$\mathrm{Ve}=27,568 \mathrm{~m}^{3}$

$\mathrm{V}_{\mathrm{c}}=10,121 \mathrm{~m}^{3}$ 
$\mathrm{Wr}=405$ ton

$\mathrm{Wg}=192$ ton

Ws $=107$ ton

Cost of other items of works such as coffering and trashrack, rake, etc. not included in themain items obtained above is estimated at $25 \%$ of the cost of the main items.

\section{Alugolla PSPP - Access Tunnel to powerhouse}

(1) Quantity of work

$\mathrm{V}_{\mathrm{e}}=2,250 \mathrm{~m}^{3}$

$\mathrm{V}_{\mathrm{c}}=500 \mathrm{~m}^{3}$

$\mathrm{W}_{\mathrm{r}}=15$ ton

Cost of other items of works such as grouting, adit, etc. not included in the main items stated

above is estimated at $15 \%$ of the cost of the main items.

\section{Alugolla PSPP -Miscellaneous Works}

Cost of miscellaneous works such as the disposal area and landscaping work is estimated at $10 \%$ of the total civil work cost.

\section{Economic Analysis}

\section{Benefit-Cost Method (B/C Method)}

The economics of the project is analyzed on the basis of maximum output, energy output and the construction cost obtained.

\section{Methodology of Analysis}

An economic analysis of the hydro power project is made by a method to compare its benefit $(B)$ and cost $(\mathrm{C})$. The benefit of a hydro power project is the avoided cost of an alternative thermal power that supplies electric power equivalent to the hydro power project, and the cost is derived from the construction cost of the hydro power project. In the case of benefit cost ratio $(\mathrm{B} / \mathrm{C})$ is 1.0 or over, hydro power is economically better than the alternative thermal power. It is also possible to judge that a certain hydro power project is economically attractive if the $\mathrm{B} / \mathrm{C}$ value is outstanding among a number of hydro power projects that are compared. Yet another method is to use the latter method and calculate the Economic Internal Rate of Return (EIRR).

\section{Selection of Alternative Thermal Power}

The alternative thermal power plants are gas turbine, coal fired, oil fired, liquefied gas fired, combined cycle, and diesel power plants.

\section{(1) Standard Thermal Power}

One method is to select the power source most commonly used in the electric power system. This is defined as the "standard thermal power". This method is suitable to compare the economic viability of a number of hydro power sites according to the same criteria, and this method is used for hydro power potential survey, master plan studies, etc. For example, in the case of an electric power system consisting mainly of coal fired thermal power plants or new coal fired plants are scheduled to be constructed, coal fired plants are selected as the standard thermal power.

\section{(2) Alternative Thermal Power Equivalent to Hydropower}

The other method is to select an alternative thermal power which is equivalent to the planned hydro power project, to evaluate its position as the source of supply in the electric power system. For instance, a gas turbine plant is often selected as the alternate thermal power for the reservoir type, pondage type and pumped storage type power plants that are designed to supply power for peak.

\section{Benefit and Cost of Conventional Hydropower Projects}

\section{Benefit}

Annual benefit (B) of a hydro power project is obtained in accordance with the following formula, based on the fixed cost (mainly the equipment cost) and variable cost (mainly the fuel cost) of the alternative thermal power selected.

$B=B_{1}+B_{2}$

$B_{1}=P h \times b_{1}$

$B_{2}=E \times b_{2}$

Where,

B: Annual benefit of hydro power plant (monetary unit)

$\mathrm{B}_{1}$ : $\mathrm{kW}$ benefit (monetary unit/kW)

$\mathrm{B}_{2}$ : kWh benefit (monetary unit/kWh)

Ph: Effective output $(\mathrm{kW})$, maximum output is used in the case of pumped storage type

E: Annual energy generation (kWh) at 2190 hours operation in a year (6hours per day)

$b_{1}$ : $\mathrm{kW}$ value (also called capacity value), which is the fixed cost per $\mathrm{kW}$ for alternative thermal power (monetary unit/kW)

$b_{2}$ : $k W h$ value (also called energy value), which is mainly the fuel cost and is the variable cost per $\mathrm{kWh}$ for alternative thermal power (monetary unit/kWh)

Loss rate and Outage rate is omitted. 


\section{Calculation of kW Value $\left(b_{1}\right)$ and $k W h$ Value $\left(b_{2}\right)$}

The $\mathrm{kW}$ value and $\mathrm{kWh}$ value are calculated from the following equations for the selected power source.

$b_{1}=C t \times \beta \times \alpha$

$b_{2}=$ Heat rate $(\mathrm{kcal} / \mathrm{kWh}) \times$ fuel price (monetary unit/kcal) $\times 860 \quad(\mathrm{kcal} / \mathrm{kWh}) /$ thermal efficiency $\times$ Fuel price (monetary unit/kcal)

$\mathrm{Ct}$ : Unit construction cost of thermal power (monetary unit/kW)

$\alpha=$ Annual cost factor of thermal power

$\beta=\mathrm{kW}$ adjustment factor; correction factor due to the difference in reliability (station use, forced outage, scheduled outage) between hydro power and thermal power.

The annual factor and thermal efficiency for gas turbine plant is shown below.

\section{Table 1 - The Annual Factor and Thermal Efficiency for Gas Turbine Plant}

\begin{tabular}{|l|l|}
\hline & Gas Turbine \\
\hline Annual cost factor & Approx. 18\% \\
\hline Thermal Efficiency & Approx. 30\% \\
\hline Service life & 20 years \\
\hline
\end{tabular}

The following equation is used to calculate more detailed annual factor.

Annual cost factor $(\alpha)=$ Capacity Recovery Factor (CRF) + Operation \& Maintenance cost (OM: fuel cost excluded)

$\alpha=C R F+O M=\frac{i(1+i)^{n}}{(1+i)^{n}-1}+0.03$

Where,

i: Interest rate

n: Service life (years) (hydro power=50years)

Economic Analysis results for Maha pumped storage power plant complex are shown in Table 6.

\section{Conclusion}

The nature has blessed Sri Lanka with several natural locations which are suitable for developing Pumped Storage Power Plants. Few sites can be developed as Pumped Storage Power Plant Complexes which, further improve their economic viability. These will reduce the transmission costs which was not considered in this study.

Results (Table 7) show that 500 MW MahaAlugolla Pumped Storage Power Plant is the most economical plant while 1,000MW Maha Pumped Storage Power Plant Complex is the next lowest.
The future load curve trends showed that there will be about 1,000MW PSPP capacity requirement by year 2021[3]. By considering the economic evaluation results and PSPP capacity requirement forecasted for the future, it can concluded that the "Maha" Pumped Storage Power Plant Complex will be the best candidate plant to be installed in Sri Lanka.

\section{References}

1. Guide manual for Development Aid Programs and Studies of Hydro Electric Power Projects, New Energy Foundation, Tokyo, Japan 1996.

2. "Study on Pumped Storage Power Plans and Optimization for Peaking Power Generation in Sri Lanka" - Volume II -Part IISite Selection and Basic Design Configuration by Ms. M.T.A.P. Wickramarathna, October 2013.

3. Planning of Pumped Storage Power Plants in Sri Lanka, M.T.A.P. Wickramarathna, SLEMA Journal, Volume 14-No.2, September 2011.

4. Forecasting Load Curve Shape for Predicting the Possible Capacity of Pumped Storage Power Plant by MTAP Wickramarathna, EMTG Jayathilake, SLEMA Journal, Volume 14-No.2, September 2011.

Note: This paper was presented in the Energy Symposium Sri Lanka 2015. 
Economic Evaluation Summary

\begin{tabular}{|c|c|c|c|c|c|c|c|c|c|c|c|c|c|c|c|}
\hline & $\begin{array}{c}\text { Construction } \\
\text { Cost (Civil) } \\
\text { (USD) }\end{array}$ & $\begin{array}{c}\text { Constructio } \\
\text { n Cost } \\
\text { (Hydro- } \\
\text { mechanical } \\
\text { Equipment } \\
\text { Cost) (USD) }\end{array}$ & $\begin{array}{c}\text { Construction } \\
\text { Cost (Eectro- } \\
\text { mechanical } \\
\text { Equipment } \\
\text { Cost) (USD) }\end{array}$ & $\begin{array}{l}\text { Total Cost } \\
\text { (USD) }\end{array}$ & $\begin{array}{r}\text { Cap } \\
\text { (M }\end{array}$ & $\begin{array}{l}\text { acity } \\
\text { IW) }\end{array}$ & $\begin{array}{r}\text { Des } \\
\text { Disch } \\
\text { Q (m }\end{array}$ & $\begin{array}{l}\text { sign } \\
\text { narge } \\
\left.n^{3} / s\right)\end{array}$ & $\begin{array}{l}\text { Effe } \\
\text { Hea }\end{array}$ & $\begin{array}{l}\text { ective } \\
\text { ad (m) }\end{array}$ & & L/H & $\begin{array}{c}\text { Project } \\
\text { cost per } \\
\text { kW } \\
\text { (USD/kW) }\end{array}$ & ERR (\%) & $\begin{array}{c}\text { Benefit } \\
\text { ICost }\end{array}$ \\
\hline Maha-Alugolla PSPP & $205,189,962$ & $62,140,374$ & $151,768,750$ & $664,702,542$ & & 500 & & 121 & & 485.2 & & 7.84 & 1,329 & $39.90 \%$ & 2.65 \\
\hline Maha PSPPC & $556,830,901$ & $172,045,045$ & $273,702,618$ & $\mid 1,600,091,621$ & $\begin{array}{l}\text { Udu. I } \\
\text { Alu. }\end{array}$ & $\begin{array}{l}500 / \\
500\end{array}$ & \begin{tabular}{|l|} 
Udu. I \\
Alu.
\end{tabular} & $\begin{array}{l}152 \\
121\end{array}$ & $\begin{array}{l}\text { Udu. I } \\
\text { Alu. }\end{array}$ & $\begin{array}{l}387.6 / \\
485.2\end{array}$ & $\begin{array}{l}\text { Udu. I } \\
\text { Alu. }\end{array}$ & $\begin{array}{l}10.64 / \\
7.84\end{array}$ & 1,600 & $34 \%$ & 2.4 \\
\hline Puna-Kotmale PSPP & $279,501,762$ & $102,958,931$ & $158,254,594$ & $859,822,180$ & & 500 & & 88 & & 666.5 & & 9.4 & 1,720 & $34 \%$ & 2.4 \\
\hline Maha-Uduw ella PSPP & $358,266,582$ & $111,385,988$ & $121,933,868$ & $948,648,602$ & & 500 & & 152 & & 387.6 & & 10.64 & 1,897 & $29.10 \%$ & 2.14 \\
\hline KM PSPP & $215,730,430$ & $57,751,710$ & $76,532,960$ & $561,841,272$ & & 250 & & 80.2 & & 366.7 & & 11.6 & 2,247 & $24.81 \%$ & 1.91 \\
\hline Dambagastalaw a PSPP & $334,948,441$ & $32,165,864$ & $93,396,154$ & $746,936,019$ & & 300 & & 79 & & 445.8 & & 6 & 2,490 & $23 \%$ & 1.8 \\
\hline Agra PSPP & $382,574,211$ & $26,241,954$ & $90,801,816$ & $813,267,607$ & & 300 & & 86.9 & & 406 & & 11 & 2,711 & $21 \%$ & 1.7 \\
\hline KMG PSPPC & $1,117,397,665$ & $116,179,268$ & $230,896,048$ & $2,383,233,673$ & $\begin{array}{l}\mathrm{KM} / \\
\mathrm{KG}\end{array}$ & $\begin{array}{l}250 / \\
500\end{array}$ & $\begin{array}{l}\mathrm{KM} / \\
\mathrm{KG}\end{array}$ & \begin{tabular}{|l|}
80.2 \\
1 \\
98.2 \\
5 \\
\end{tabular} & $\begin{array}{l}\text { KM } / \\
\text { KG }\end{array}$ & $\begin{array}{l}366.7 / \\
598.7\end{array}$ & $\begin{array}{l}\mathrm{KM} / \\
\mathrm{KG}\end{array}$ & $\begin{array}{l}11.6 / \\
9.0\end{array}$ & 3,178 & $18 \%$ & 1.5 \\
\hline KG PSPP & $904,786,946$ & $58,418,642$ & $154,363,088$ & $1,826,567,624$ & & 500 & & 98.25 & & 598.7 & & 9 & 3,653 & $15.35 \%$ & 1.35 \\
\hline
\end{tabular}

Calculation of Construction Cost (Civil Cost)-Maha PSPP Complex

\begin{tabular}{|c|c|c|c|c|c|}
\hline Item & Unit & Unit Price & Quantity & Cost & Remark \\
\hline \multicolumn{6}{|l|}{ (1) Upper dam } \\
\hline 1. Care of river & L.S. & - & 1 & $28,269,870$ & 1. $=2 . \times 0.20$ \\
\hline 2. Concrete dam & & & & & 2. $=(1+2+3$ \\
\hline (1)Excavation & $\mathrm{m}^{3}$ & 22 & 215,400 & $4,727,942$ & (1) \\
\hline (2) Concrete & $\mathrm{m}^{3}$ & 262 & 432,255 & $113,063,183$ & (2) \\
\hline (3) Others & L.S. & - & 1 & $23,558,225$ & (3) $=(1)+2) \times 0.2$ \\
\hline Sub Total & & & & $169,619,220$ & \\
\hline \multicolumn{6}{|l|}{ (2) Lower dam } \\
\hline 1. Care of river & L.S. & - & 1 & $12,472,633$ & 1. $=2 . \times 0.2$ \\
\hline 2. Concrete dam & & & & & 2. $=(1+2+3$ \\
\hline (1)Excavation & $\mathrm{m}^{3}$ & 22 & 199,500 & $4,378,944$ & (1) \\
\hline (2) Concrete & $\mathrm{m}^{3}$ & 262 & 181,944 & $47,590,360$ & (2) \\
\hline (3) Others & L.S. & - & 1 & $10,393,861$ & (3) $=(1)+(2) \times 0.2$ \\
\hline Sub Total & & & & $744,835,797$ & \\
\hline \multicolumn{6}{|l|}{ (3) Intake } \\
\hline (1) Excavation & $\mathrm{m}^{3}$ & 22 & 51,583 & $1,132,234$ & (1) \\
\hline (2) Concrete & $\mathrm{m}^{3}$ & 273 & 18,978 & $5,172,258$ & (2) \\
\hline (3) Reinforcement bar & ton & 2,625 & 759 & $1,992,534$ & (3) \\
\hline (4) Others & L.S. & - & 1 & $2,074,256$ & (4) $=(1)+(2)+(3) \times 0.25$ \\
\hline Sub Total & & & & $10,371,282$ & \\
\hline \multicolumn{6}{|l|}{ (4) Headrace } \\
\hline (1) Excavation & $\mathrm{m}^{3}$ & 134 & 136,115 & $18,175,012$ & (1) \\
\hline (2) Concrete & $\mathrm{m}^{3}$ & 267 & 42,813 & $11,433,315$ & (2) \\
\hline (3)Reinforcement bar & ton & 2,625 & 1,713 & $4,495,016$ & (3) \\
\hline (4) Others & L.S. & - & 1 & $5,115,501$ & (4) $=(1)+(2)+(3) \times 0.15$ \\
\hline Sub Total & & & & $39,218,844$ & \\
\hline \multicolumn{6}{|c|}{ (5) Surge tank (Headrace) } \\
\hline (1) Excavation & $\mathrm{m}^{3}$ & 172 & 70,093 & $12,051,612$ & (1) \\
\hline (2)Concrete & $\mathrm{m}^{3}$ & 216 & 20,290 & $4,379,337$ & (2) \\
\hline (3)Reinforcement bar & ton & 2,625 & 1,014 & $2,662,860$ & (3) \\
\hline (4) Others & L.S. & - & 1 & $3,818,762$ & (4) $=(1)+(2)+(3) \times 0.2$ \\
\hline Sub Total & & & & $22,912,570$ & \\
\hline
\end{tabular}


SLEMA Journal, Volume 18, No. 2, September 2015

\begin{tabular}{|c|c|c|c|c|c|}
\hline \multicolumn{6}{|l|}{ (4) Penstock } \\
\hline (1)Excavation & $\mathrm{m}^{3}$ & 199 & 86,034 & $17,153,029$ & (1) \\
\hline (2) Concrete & $\mathrm{m}^{3}$ & 190 & 33,799 & $6,429,569$ & (2) \\
\hline (3) Others & L.S. & - & 1 & $3,537,390$ & (3) $=(1)+(2) \times 0.15$ \\
\hline Sub Total & & & & $27,119,988$ & \\
\hline \multicolumn{6}{|l|}{ (5) Powerhouse } \\
\hline (1) Excavation & $\mathrm{m}^{3}$ & 209 & 278,598 & $58,093,626$ & (1) \\
\hline (2) Concrete & $\mathrm{m}^{3}$ & 424 & 52,898 & $22,447,903$ & (2) \\
\hline (3) Reinforcement bar & ton & 2,625 & 2,116 & $5,553,921$ & (3) \\
\hline (4)Others & L.S. & - & 1 & $43,047,725$ & (4) $=(1)+(2)+(3) \times 0.5$ \\
\hline Sub Total & & & & $129,143,175$ & \\
\hline \multicolumn{6}{|l|}{ (6) Tailrace } \\
\hline (1) Excavation & $\mathrm{m}^{3}$ & 134 & 20,199 & $2,697,057$ & (1) \\
\hline (2) Concrete & $\mathrm{m}^{3}$ & 267 & 6,318 & $1,687,252$ & (2) \\
\hline (3) Reinforcement bar & ton & 2,625 & 253 & 663,344 & (3) \\
\hline (4) Others & L.S. & - & 1 & 757,148 & $(4)=(1)+(2)+(3) \times 0.15$ \\
\hline Sub Total & & & & $5,804,802$ & \\
\hline \multicolumn{6}{|l|}{ (7) Surge tank (Tailrace) } \\
\hline (1) Excavation & $\mathrm{m}^{3}$ & 172 & 43,895 & $7,547,290$ & (1) \\
\hline (2) Concrete & $\mathrm{m}^{3}$ & 216 & 12,707 & $2,742,548$ & (2) \\
\hline (3) Reinforcement bar & ton & 2,625 & 635 & $1,667,609$ & (3) \\
\hline (4) Others & L.S. & - & 1 & $2,391,489$ & $(4)=(1)+(2)+(3) \times 0.2$ \\
\hline Sub Total & & & & $14,348,936$ & \\
\hline \multicolumn{6}{|l|}{ (8) Outlet } \\
\hline (1) Excavation & $\mathrm{m}^{3}$ & 22 & 59,749 & $1,311,476$ & (1) \\
\hline (2) Concrete & $\mathrm{m}^{3}$ & 273 & 21,879 & $5,962,897$ & (2) \\
\hline (3)Reinforcement bar & ton & 2,625 & 875 & $2,297,116$ & (3) \\
\hline (4) Others & L.S. & - & 1 & $2,392,872$ & $(4)=(1)+2)+(3) \times 0.25$ \\
\hline Sub Total & & & & $111,964,361$ & \\
\hline \multicolumn{6}{|l|}{ (9) Access tunnel to } \\
\hline (1) Excavation & $\mathrm{m}^{3}$ & 134 & 3,600 & 480,696 & (1) \\
\hline (2)Concrete & $\mathrm{m}^{3}$ & 267 & 800 & 213,643 & (2) \\
\hline (3) Reinforcement bar & ton & 2,625 & 24 & 62,995 & (3) \\
\hline (4)Others & L.S. & - & 1 & 113,600 & (4) $=(1)+(2)+(3) \times 0.15$ \\
\hline Sub Total & & & & 870,934 & \\
\hline (10) Miscellaneous & L.S. & - & & $50,620,991$ & $(10)=\Sigma\{(1 \sim 9)\} \times 0.1$ \\
\hline Total & & & & $556,830,901$ & \\
\hline
\end{tabular}


Calculation of Construction Cost (Hydro Mechanical Equipment Cost) - Maha PSPP Complex

\begin{tabular}{|c|c|c|c|c|c|}
\hline Item & Unit & Unit & Quantity & Cost & Remark \\
\hline \multicolumn{6}{|c|}{ 1. Upper Dam and spillway } \\
\hline Gate & ton & 12,842 & 34 & 433,169 & \\
\hline \multicolumn{6}{|c|}{ 2. Lower Dam and spillway } \\
\hline Gate & ton & 12,842 & 157 & $2,013,642$ & \\
\hline \multicolumn{6}{|l|}{ 3. Intake } \\
\hline Gate & ton & 10,767 & 430 & $4,634,876$ & \\
\hline Screen & ton & 5,578 & 239 & $1,334,001$ & \\
\hline 4. Penstock (steel pipe) & ton & 6,097 & 21,141 & $128,892,381$ & \\
\hline \multicolumn{6}{|l|}{ 5. Tailrace outlet } \\
\hline Gate & ton & 10,767 & 437 & $4,707,810$ & \\
\hline Screen & ton & 5,578 & 243 & $1,354,992$ & \\
\hline 6. Others & L.S. & - & 1 & $28,674,174$ & $\begin{array}{l}(1+2+3+4) \times \\
0.2\end{array}$ \\
\hline Total & & & & $172,045,045$ & \\
\hline
\end{tabular}

\section{Construction Cost Summery - Maha PSPP Complex}

\begin{tabular}{|c|c|c|}
\hline Item & Cost (USD) & Note \\
\hline $\begin{array}{l}\text { 1. Preparation and Land acquisition } \\
\text { (1) Access road } \\
\text { (2) Compensation \& Resettlement } \\
\text { (3) Camp \& Facilities }\end{array}$ & $\begin{array}{r}27,841,545 \\
11,136,618\end{array}$ & $\begin{array}{l}(3 \text { Civil work }) \times 0.05 \\
(3 \text { Civil work }) \times 0.02\end{array}$ \\
\hline 2. Environmental mitigation cost & $16,704,927$ & $(3$ Civil work $) \times 0.03$ \\
\hline $\begin{array}{l}\text { 3. Civil Work } \\
\text { (1) Upper Dams } \\
\text { (2) Lower Dam } \\
\text { (3) Intakes } \\
\text { (4) Headrace } \\
\text { (5) Surge tank (Headrace) } \\
\text { (6) Penstocks } \\
\text { (7) Powerhouses } \\
\text { (8) Tailraces } \\
\text { (9) Surge tanks (tailrace) } \\
\text { (10) Outlets } \\
\text { (11) Access tunnels to powerhouses } \\
\text { (12) Miscellaneous }\end{array}$ & $\begin{array}{r}169,619,220 \\
74,835,797 \\
10,371,282 \\
39,218,844 \\
22,912,570 \\
27,119,988 \\
129,143,175 \\
5,804,802 \\
14,348,936 \\
11,964,361 \\
870,934 \\
50,620,991 \\
\end{array}$ & $((1) \sim(9)) \times 0.1$ \\
\hline 4. Hydraulic equipment & $172,045,045$ & Gate, Screen, Steel Penstock, etc \\
\hline 5. Electro-mechanical equipment & $273,702,618$ & $\begin{array}{l}\text { Turbine and Generator, Transformer, } \\
\text { Switchyard, etc }\end{array}$ \\
\hline \multicolumn{3}{|l|}{ 6. Transmission line } \\
\hline Direct cost & $1,058,261,654$ & $1+2+3+4+5+6$ \\
\hline $\begin{array}{l}\text { 7. Administration and Engineering } \\
\text { service }\end{array}$ & $158,739,248$ & $($ Direct cost $) \times 0.15$ \\
\hline 8. Contingency & $211,652,331$ & $($ Direct cost $) \times 0.2$ \\
\hline 9. Interest during construction & $171,438,388$ & $\begin{array}{l}(1+2+3+4+5+6+7+8) \times 0.4 \times 6 \% \times \\
5 \text { year }\end{array}$ \\
\hline Indirect Cost & $541,829,967$ & $7+8+9$ \\
\hline Total cost & $1,600,091,621$ & $1+2+3+4+5+6+7+8+9$ \\
\hline Install Capacity & $1,000,000$ & $(\mathrm{~kW})$ \\
\hline Project Cost per kW & 1,600 & $(\mathrm{USD} / \mathrm{kW})$ \\
\hline
\end{tabular}


Calculation of Economic Evaluation Indices (Base Case) - Maha PSPP Complex

\begin{tabular}{|c|c|c|c|c|c|c|c|c|c|c|c|}
\hline \multirow[b]{2}{*}{$\begin{array}{l}\text { Year } \\
\text { in } \\
\text { order }\end{array}$} & & \multirow[b]{2}{*}{ Year } & \multicolumn{4}{|c|}{ Cost } & \multicolumn{5}{|c|}{ Benefit(Unit: US $\$ 1,000,000)$} \\
\hline & & & $\begin{array}{c}\text { Construction } \\
\& \\
\text { Replacement }\end{array}$ & $\mathrm{O} \& \mathrm{M}$ & Pumping & Total & $\begin{array}{c}\text { Construction } \\
\& \\
\text { Replacement }\end{array}$ & $\begin{array}{c}\mathrm{O} \& \\
\mathrm{M}\end{array}$ & $\begin{array}{l}\text { Fuel } \\
\text { Cost }\end{array}$ & Total & Balance \\
\hline 1 & & 2015 & 100.26 & & & 100.26 & & & & 0.00 & $(100.26)$ \\
\hline 2 & & 2016 & 200.52 & & & 200.52 & & & & 0.00 & (200.52) \\
\hline 3 & & 2017 & 300.77 & & & 300.77 & & & & 0.00 & (300.77) \\
\hline 4 & & 2018 & 300.77 & & & 300.77 & 260.48 & & & 260.48 & $(40.30)$ \\
\hline 5 & & 2019 & 100.26 & & & 100.26 & 362.40 & & & 362.40 & 262.14 \\
\hline 6 & 1 & 2020 & & 30.08 & 92.05 & 122.13 & & 8.07 & 499.83 & 507.91 & 385.78 \\
\hline 7 & 2 & 2021 & & 30.08 & 92.05 & 122.13 & & 8.07 & 499.83 & 507.91 & 385.78 \\
\hline 8 & 3 & 2022 & & 30.08 & 92.05 & 122.13 & & 8.07 & 499.83 & 507.91 & 385.78 \\
\hline 9 & 4 & 2023 & & 30.08 & 92.05 & 122.13 & & 8.07 & 499.83 & 507.91 & 385.78 \\
\hline 10 & 5 & 2024 & & 30.08 & 92.05 & 122.13 & & 8.07 & 499.83 & 507.91 & 385.78 \\
\hline 11 & 6 & 2025 & & 30.08 & 92.05 & 122.13 & & 8.07 & 499.83 & 507.91 & 385.78 \\
\hline 12 & 7 & 2026 & & 30.08 & 92.05 & 122.13 & & 8.07 & 499.83 & 507.91 & 385.78 \\
\hline 13 & 8 & 2027 & & 30.08 & 92.05 & 122.13 & & 8.07 & 499.83 & 507.91 & 385.78 \\
\hline 14 & 9 & 2028 & & 30.08 & 92.05 & 122.13 & & 8.07 & 499.83 & 507.91 & 385.78 \\
\hline 15 & 10 & 2029 & & 30.08 & 92.05 & 122.13 & & 8.07 & 499.83 & 507.91 & 385.78 \\
\hline 16 & 11 & 2030 & & 30.08 & 92.05 & 122.13 & & 8.07 & 499.83 & 507.91 & 385.78 \\
\hline 17 & 12 & 2031 & & 30.08 & 92.05 & 122.13 & & 8.07 & 499.83 & 507.91 & 385.78 \\
\hline 18 & 13 & 2032 & & 30.08 & 92.05 & 122.13 & & 8.07 & 499.83 & 507.91 & 385.78 \\
\hline 19 & 14 & 2033 & & 30.08 & 92.05 & 122.13 & & 8.07 & 499.83 & 507.91 & 385.78 \\
\hline 20 & 15 & 2034 & & 30.08 & 92.05 & 122.13 & & 8.07 & 499.83 & 507.91 & 385.78 \\
\hline 21 & 16 & 2035 & & 30.08 & 92.05 & 122.13 & & 8.07 & 499.83 & 507.91 & 385.78 \\
\hline 22 & 17 & 2036 & & 30.08 & 92.05 & 122.13 & & 8.07 & 499.83 & 507.91 & 385.78 \\
\hline 23 & 18 & 2037 & & 30.08 & 92.05 & 122.13 & & 8.07 & 499.83 & 507.91 & 385.78 \\
\hline 24 & 19 & 2038 & & 30.08 & 92.05 & 122.13 & 260.48 & 8.07 & 499.83 & 768.38 & 646.25 \\
\hline 25 & 20 & 2039 & & 30.08 & 92.05 & 122.13 & 362.40 & 8.07 & 499.83 & 870.31 & 748.18 \\
\hline 26 & 21 & 2040 & & 30.08 & 92.05 & 122.13 & & 8.07 & 499.83 & 507.91 & 385.78 \\
\hline 27 & 22 & 2041 & & 30.08 & 92.05 & 122.13 & & 8.07 & 499.83 & 507.91 & 385.78 \\
\hline 28 & 23 & 2042 & & 30.08 & 92.05 & 122.13 & & 8.07 & 499.83 & 507.91 & 385.78 \\
\hline 29 & 24 & 2043 & & 30.08 & 92.05 & 122.13 & & 8.07 & 499.83 & 507.91 & 385.78 \\
\hline 30 & 25 & 2044 & & 30.08 & 92.05 & 122.13 & & 8.07 & 499.83 & 507.91 & 385.78 \\
\hline 31 & 26 & 2045 & & 30.08 & 92.05 & 122.13 & & 8.07 & 499.83 & 507.91 & 385.78 \\
\hline 32 & 27 & 2046 & & 30.08 & 92.05 & 122.13 & & 8.07 & 499.83 & 507.91 & 385.78 \\
\hline 33 & 28 & 2047 & & 30.08 & 92.05 & 122.13 & & 8.07 & 499.83 & 507.91 & 385.78 \\
\hline 34 & 29 & 2048 & & 30.08 & 92.05 & 122.13 & & 8.07 & 499.83 & 507.91 & 385.78 \\
\hline 35 & 30 & 2049 & & 30.08 & 92.05 & 122.13 & & 8.07 & 499.83 & 507.91 & 385.78 \\
\hline 36 & 31 & 2050 & 61.78 & 30.08 & 92.05 & 183.91 & & 8.07 & 499.83 & 507.91 & 324.00 \\
\hline 37 & 32 & 2051 & 44.57 & 30.08 & 92.05 & 166.70 & & 8.07 & 499.83 & 507.91 & 341.20 \\
\hline 38 & 33 & 2052 & 179.86 & 30.08 & 92.05 & 301.99 & & 8.07 & 499.83 & 507.91 & 205.92 \\
\hline 39 & 34 & 2053 & 114.96 & 30.08 & 92.05 & 237.09 & & 8.07 & 499.83 & 507.91 & 270.82 \\
\hline 40 & 35 & 2054 & 44.57 & 30.08 & 92.05 & 166.70 & & 8.07 & 499.83 & 507.91 & 341.20 \\
\hline 41 & 36 & 2055 & & 30.08 & 92.05 & 122.13 & & 8.07 & 499.83 & 507.91 & 385.78 \\
\hline 42 & 37 & 2056 & & 30.08 & 92.05 & 122.13 & & 8.07 & 499.83 & 507.91 & 385.78 \\
\hline 43 & 38 & 2057 & & 30.08 & 92.05 & 122.13 & & 8.07 & 499.83 & 507.91 & 385.78 \\
\hline 44 & 39 & 2058 & & 30.08 & 92.05 & 122.13 & 260.48 & 8.07 & 499.83 & 768.38 & 646.25 \\
\hline 45 & 40 & 2059 & & 30.08 & 92.05 & 122.13 & 362.40 & 8.07 & 499.83 & 870.31 & 748.18 \\
\hline 46 & 41 & 2060 & & 30.08 & 92.05 & 122.13 & & 8.07 & 499.83 & 507.91 & 385.78 \\
\hline 47 & 42 & 2061 & & 30.08 & 92.05 & 122.13 & & 8.07 & 499.83 & 507.91 & 385.78 \\
\hline 48 & 43 & 2062 & & 30.08 & 92.05 & 122.13 & & 8.07 & 499.83 & 507.91 & 385.78 \\
\hline 49 & 44 & 2063 & & 30.08 & 92.05 & 122.13 & & 8.07 & 499.83 & 507.91 & 385.78 \\
\hline 50 & 45 & 2064 & & 30.08 & 92.05 & 122.13 & & 8.07 & 499.83 & 507.91 & 385.78 \\
\hline 51 & 46 & 2065 & & 30.08 & 92.05 & 122.13 & & 8.07 & 499.83 & 507.91 & 385.78 \\
\hline 52 & 47 & 2066 & & 30.08 & 92.05 & 122.13 & & 8.07 & 499.83 & 507.91 & 385.78 \\
\hline 53 & 48 & 2067 & & 30.08 & 92.05 & 122.13 & & 8.07 & 499.83 & 507.91 & 385.78 \\
\hline 54 & 49 & 2068 & & 30.08 & 92.05 & 122.13 & & 8.07 & 499.83 & 507.91 & 385.78 \\
\hline 55 & 50 & 2069 & & 30.08 & 92.05 & 122.13 & & 8.07 & 499.83 & 507.91 & 385.78 \\
\hline 56 & 51 & 2070 & & 30.08 & 92.05 & 122.13 & & 8.07 & 499.83 & 507.91 & 385.78 \\
\hline \multicolumn{3}{|c|}{ Total } & $1,448.33$ & $1,533.95$ & $4,694.64$ & $7,676.91$ & $1,868.63$ & 411.79 & $25,491.47$ & $27,771.89$ & $20,094.98$ \\
\hline \multicolumn{12}{|c|}{ In the condition of a discount rate of $10 \%$ : } \\
\hline \multicolumn{6}{|c|}{ Present value: } & 1,515 & & & & 3,601 & $2,086.14$ \\
\hline \multicolumn{11}{|c|}{ Economic Internal rate of return (EIRR): } & $33.98 \%$ \\
\hline \multicolumn{11}{|l|}{$\mathrm{B} / \mathrm{C}$} & 2.38 \\
\hline
\end{tabular}

